\title{
Pengaruh Kecerdasan Emosional Terhadap Efektivitas Kerja Karyawan
}

\author{
${ }^{1}$ Ichwan Saputra Siregar, ${ }^{2}$ Muhammad Rizal, ${ }^{3}$ Delfi Andreni Siregar, ${ }^{4}$ Shafa Anugrah Lubis \\ ${ }^{1-4}$ Program Magister Manajemen, Fakultas Ekonomi, Universitas Islam Sumatera Utara
}

Article history

Received: 12 Jan 2021

Revised: 20 Feb 2021

Accepted: 02 Mar 2021

*Corresponding Author:

Ichwan Saputra Siregar,

Program Studi Magister

Manajemen, Fakultas

Ekonomi, Universitas Islam

Sumatera Utara

Email:

$\underline{\text { muhammadrizal3@gmail.co }}$

$\underline{\mathrm{m}}$
Abstrak: Penelitian ini akan menganalisis pengaruh iklim organisasi terhadap efektivitas kerja karyawan di PT. Bank Aceh Syariah cabang Meureudu. Penelitian menggunakan pendekatan kuantitatif deskriptif. Sampel yang diambil sebanyak berjumlah 34 orang yang merupakan karyawan karyawan di PT. Bank Aceh Syariah Cabang Meureudu dengan klasifikasi tingkat pendidikan SMA sebanyak 3 orang $(8,8 \%)$, Diploma sebanyak 3 orang $(8,8 \%)$, Sarjana sebanyak 26 orang $(76,5 \%)$, dan Pasca Sarjana sebanyak 2 orang $(5,9 \%)$. Serta perbandinga dari jenis kelamin responden yang berjenis kelamin laki-laki berjumlah 22 orang $(64,7 \%)$ dan perempuan 12 orang (35,3\%). Dari angket yang diberikan kepada 34 orang responden, setiap responden menjawab 40 pertanyaan dari variabel bebas dan terikat. Dari hasil analisa penelitian yang dilakukan dengan bantuan software SPSS, diperoleh hasil bahwa variabel kecerdasan emosional berpengaruh positif dan signifikan terhadap efektivitas kerja karyawan di PT. Bank Aceh Syariah Cabang Meureudu.

Kata Kunci : Pengaruh, Kecerdasan Emosional, Efektifitas Kerja, Karyawan.

\section{PENDAHULUAN}

Penting untuk mengaktualisasikan atau merealisasikan dirinya untuk menemukan dan mengembangkan jati dirinya masing-masing. Sehingga, setiap individu diperlukan berbagai bantuan atau kerja sama dari individu lain. Dalam keadaan seperti itu, manusia berusaha mengatur kebersamaannya, baik dalam bentuk kelompok kecil maupun besar. Sehingga efektivitas kerja dapat tercapai dengan baik Menurut Handoko (2012:99) efektivitas kerja adalah penyelesaian pekerjaan tepat pada waktu yang ditentukan, dimana semakin cepat pekerjaan itu terselesaikan dengan ketentuan yang ditetapkan, maka akan semakin baik pula efektivitas kerja yang dicapai. Dalam meningkatkan efektivitas kerja karyawan Bank Aceh Syariah Cabang Meureudu memprediksi bahwa faktor kecerdasan emosional, kompetensi dan iklim organisasi menjadi faktor-faktor yang dapat berpengaruh terhadap efektivitas kerja karyawan. Demikian pula sebaliknya dengan semakin lamanya pekerjaan tersebut terselesaikan, maka semakin jauh pula pekerjaan tersebut dari keefektifannya.

Dalam meningkatkan efektivitas kerja karyawan Bank Aceh Syariah Cabang Meureudu memprediksi bahwa faktor kecerdasan emosional menjadi faktor-faktor yang dapat berpengaruh terhadap efektivitas kerja karyawan. Agustian (2001) mendefinisikan kecerdasan emosional merupakan kemampuan merasakan, memahami, dan secara efektif menerapkan daya dan kepekaan emosi sebagai sumber energi, informasi, koneksi dan pengaruh yang manusiawi. Individu yang mampu memahami emosi individu lain, dapat bersikap dan mengambil keputusan dengan tepat tanpa menimbulkan dampak yang merugikan kedua belah pihak. Emosi dapat timbul setiap kali individu mendapatkan rangsangan yang dapat mempengaruhi kondisi jiwa dan menimbulkan gejolak dari dalam. Emosi yang dikelola dengan baik dapat dimanfaatkan untuk mendukung keberhasilan dalam berbagai bidang karena pada waktu emosi muncul, individu memiliki energi lebih dan mampu mempengaruhi individu lain. Segala sesuatu yang dihasilkan emosi tersebut bila 
dimanfaatkan dengan benar dapat diterapkan sebagai sumber energi yang diperlukan untuk menyelesaikan tugas.

Selain itu, Iman (2004) juga mendefinisikan kecerdasan emosional sebagai himpunan suatu fungsi jiwa yang melibatkan kemampuan memantau intensitas perasaan atau emosi, baik pada diri sendiri maupun pada orang lain. Individu memiliki kecerdasan emosional tinggi memiliki keyakinan tentang dirinya sendiri, penuh antusias, pandai memilah semuanya dan menggunakan informasi sehingga dapat membimbing pikiran dan tindakan. Kecerdasan emosional bukan didasarkan pada kepintaran seorang anak melainkan pada suatu yang dahulu disebut "karakter" atau "karakteristik pribadi". Penelitian-penelitian mutakhir menemukan bahwa keterampilan sosial dan emosional lebih penting bagi keberhasilan hidup ketimbang kemampuan intelektual (Darwis, 2007:49).

Salah satu variabel yang mempengaruhi efektivitas kerja karyawan di Bank Aceh Syariah Cabang Meureudu adalah kecerdasan emosional. Karena kecerdasan emosional untuk mengenali emosi diri, mengelola emosi, mengenali emosi orang lain, dan membina hubungan dengan orang lain (Goleman (2006). Begitu juga pandangan Cooper dan Sawaf (1997) bahwa kecerdasan emosi adalah kemampuan merasakan, memahami dan secara efektif menerapkan daya dan kepekaan emosi sebagai sumber energi, informasi, koreksi dan pengaruh yang manusiawi. Kecerdasan emosi menuntut penilikan perasaan untuk belajar mengakui, menghargai perasaan pada diri dan orang lain serta menanggapinya dengan tepat, menerapkan secara efektif energi emosi dalam kehidupan sehari-hari.

\section{METODE PENELITIAN}

Teknik pengumpulan data dilakukan dengan pengumpulan data primer dan data sekunde. Dalam penelitian ini data diperoleh dari studi perpustakaan dan lembaga atau objek penelitian.vTeknik analisis data menggunakan analisis deskriptif dan kuantitatif. Pada bagian ini analisis deskriptif dibahas mengenai bentuk sebaran jawaban responden terhadap keseluruhan konsep yang diukur. Dari sebaran jawaban responden tersebut, selanjutnya akan diperoleh sebuah kecenderungan dari seluruh jawaban yang ada. Untuk mendapat kecenderungan jawaban responden terhadap masing-masing variabel, akan didasarkan pada nilai skor rata-rata (indeks) yang dikategorikan ke dalam rentang skor berdasarkan perhitungan three box method. Kemudian pada analisis kuantitatif data tersebut harus diklarifikasi dalam kategori tertentu dengan menggunakan tabel-tabel tertentu, untuk mempermudah dalam menganalisa dengan menggunakan program SPSS for windows versi 25.00, dimana bertujuan untuk mengetahui pengaruh variabel independen terhadap variabel dependen dengan menggunakan analisis regresi linear berganda.

Selanjutnya untuk menguji kualitas data digunakan merode uji kualitas data yang terdiri dari uji validitas dan uji Reliabilitas. Setelah uji validitas maka dilakukan uji asumsi publik dalam penelitian ini untuk menguji hipotesis penelitian menggunakan analisis regresi linier berganda yaitu melihat pengaruh bebas terhadap variabel terikat. Persyaratan dalam analisis regresi adalah uji asumsi klasik. Pengujian asumsi klasik diperlukan untuk mengetahui apakah hasil estimasi regresi yang dilakukan, benar-benar bebas dari adanya gejala heteroskedastisitas, gejala multikolinearitas, gejala autokorelasi dan gejala normalitas. Lalu yang terakhir digunakan metode pengujian hipotesis secara parsial dilakukan dengan uji t. Pengujian uji t sig yaitu dengan melihat tingkat pengaruh yang signifikan yang didasarkan 
pada $\rho$ value $<\alpha=5 \%$. Atau melihat nilai t-hitung harus lebih besar dari t-tabel. Sebaliknya jika t-hitung < dari t-tabel maka pengaruh yang terjadi tidak signifikan.

Sedangkan untuk menguji ada tidaknya pengaruh dari variabel bebas secara menyeluruh/simultan terhadap variabel terikat dilakukan dengan uji F. Uji ini menggunakan $\rho$ value $<\alpha=5 \%$. Dengan ketentuan, jika F-hitung $>$ dari F-tabel maka hipotesis yang diajukan dapat diterima atau dapat dinilai berdasarkan hasil uji hipotesis yang ditunjukkan oleh tabel koefisien pada kolom signifikansi, yang menunjukkan nilai $<\alpha=5 \%$. Penggujian hipotesis menggunakan aplikasi SPSS version 25.00.

\section{HASIL DAN PEMBAHASAN}

Penelitian dilakukan pada karyawan karyawan di PT. Bank Aceh Syariah Cabang Meureudu dengan klasifikasi tingkat pendidikan SMA/sederajat sebanyak 3 orang $(8,8 \%)$, Diploma sebanyak 3 orang $(8,8 \%)$, Sarjana sebanyak 26 orang (76,5\%), dan Pasca Sarjana sebanyak 2 orang $(5,9 \%)$. Serta perbandinga dari jenis kelamin responden yang berjenis kelamin laki-laki berjumlah 22 orang $(64,7 \%)$ dan perempuan 12 orang $(35,3 \%)$.

Dari angket yang diberikan kepada 34 orang responden, setiap responden menjawab 40 pertanyaan dari variabel bebas dan terikat. Maka penulis mentabulasi hasil jawaban angket untuk masing-masing variabel, dengan rincian skor angket dari tiap-tiap variabel.

Tabel 1. Statistik Deskriptif

\begin{tabular}{|c|c|c|c|c|c|c|c|}
\hline \multirow{2}{*}{ Variabel } & \multirow{2}{*}{ Instrumen } & \multicolumn{6}{|c|}{ Frekuensi (dalam persentase) } \\
\hline & & 5 & 4 & 3 & 2 & 1 & Total \\
\hline \multirow{10}{*}{$\begin{array}{l}\text { Kecerdasan } \\
\text { emosional }\left(\mathrm{X}_{1}\right)\end{array}$} & 1. KE1 & 55,9 & 26,5 & 11,8 & 5,9 & 0,0 & 100 \\
\hline & 2. KE2 & 32,4 & 44,1 & 17,6 & 5,9 & 0,0 & 100 \\
\hline & 3. KE3 & 38,2 & 52,9 & 8,8 & 0,0 & 0,0 & 100 \\
\hline & 4. KE4 & 41,2 & 41,2 & 8,8 & 8,8 & 0,0 & 100 \\
\hline & 5. KE5 & 17,6 & 50,0 & 29,4 & 2,9 & 0,0 & 100 \\
\hline & 6. KE6 & 35,3 & 52,9 & 5,9 & 5,9 & 0,0 & 100 \\
\hline & 7. KE7 & 14,7 & 44,1 & 26,5 & 14,7 & 0,0 & 100 \\
\hline & 8. KE8 & 14,7 & 50,0 & 26,5 & 8,8 & 0,0 & 100 \\
\hline & 9. KE9 & 5,9 & 58,8 & 20,6 & 11,8 & 2,9 & 100 \\
\hline & 10. KE10 & 26,5 & 41,2 & 17,6 & 14,7 & 0,0 & 100 \\
\hline \multirow{10}{*}{$\begin{array}{l}\text { Efektivitas kerja } \\
\text { (Y1) }\end{array}$} & 1. EK1 & 8,8 & 55,9 & 23,5 & 11,8 & 0,0 & 100 \\
\hline & 2. EK2 & 14,7 & 61,8 & 14,7 & 8,8 & 0,0 & 100 \\
\hline & 3. EK3 & 35,3 & 44,1 & 17,6 & 2,9 & 0,0 & 100 \\
\hline & 4. EK4 & 176 & 52,9 & 17,6 & 11,8 & 0,0 & 100 \\
\hline & 5. EK5 & 17,6 & 20,6 & 47,1 & 17,6 & 0,0 & 100 \\
\hline & 6. EK6 & 14,7 & 58,8 & 14,7 & 11,8 & 0,0 & 100 \\
\hline & 7. EK7 & 14,7 & 29,4 & 55,9 & 5,9 & 0,0 & 100 \\
\hline & 8. EK8 & 8,8 & 55,9 & 2,9 & 5,9 & 0,0 & 100 \\
\hline & 9. EK9 & 35,3 & 11,8 & 29,4 & 41,2 & 2,9 & 100 \\
\hline & 10.EK10 & $\begin{array}{l}14,7 \\
23,5\end{array}$ & 17,6 & 29,4 & 23,5 & 5,9 & 100 \\
\hline
\end{tabular}




\section{Variabel Kecerdasan Emosional $\left(\mathbf{X}_{1}\right)$}

Jawaban responden untuk pernyataan No. 1: Saya bersikap cuek terhadap permasalahan yang dihadapi rekan kerja.Responden yang menjawab sangat setuju 19 orang $(55,88 \%)$, setuju 9 orang $(26,47 \%)$, kurang setuju 4 orang $(11,77 \%)$, dan tidak setuju 2 orang $(5,88 \%)$.

Jawaban responden untuk pernyataan No. 2: Saya mampu mengontrol emosi dalam situasi apapun.Responden yang menjawab sangat setuju 11 orang $(32,35 \%)$, setuju 15 orang $(44,12 \%)$, kurang setuju 6 orang $(17,65 \%)$, dan tidak setuju 2 orang $(5,88 \%)$.

Jawaban responden untuk pernyataan No. 3: Saya akan mempertahankan pendapat saya, meskipun rekan kerja menolaknya. Responden yang menjawab sangat setuju 13 orang $(38,24 \%)$, setuju 18 orang (52,94\%), dan kurang setuju 3 orang $(8,82 \%)$.

Jawaban responden untuk pernyataan No. 4: Saya mampu menjaga ketersinggungan dari akibat-akibat yang timbul karena kegagalan mengontrol emosi. Responden yang menjawab sangat setuju 14 orang $(41,18 \%)$, setuju 14 orang $(41,18 \%)$, kurang setuju 3 orang $(8,82 \%)$, dan tidak setuju 3 orang $(8,82 \%)$.

Jawaban responden untuk pernyataan No.5: Saya terganggu dengan peraturanperaturan yang berlaku. Responden yang menjawab sangat setuju 6 orang (17,65\%), setuju 17 orang (50\%), kurang setuju 10 orang $(29,41 \%)$, dan tidak setuju 1 orang $(2,94 \%)$.

Jawaban responden untuk pernyataan No. 6: Saya tidak peduli dengan respon orang lain tentang perilaku yang saya lakukan. Responden yang menjawab sangat setuju 12 orang $(35,29 \%)$, setuju 18 orang $(52,94 \%)$, kurang setuju 2 orang $(5,88 \%)$, dan tidak setuju 2 orang $(5,88 \%)$.

Jawaban responden untuk pernyataan No. 7 Saya menyukai rekan kerja membantu / mengarahkan dalam menyelesaikan tugas / tanggung jawab yang diberikan. Responden yang menjawab sangat setuju 5 orang $(14,71 \%)$, setuju 15 orang $(44,12 \%)$, kurang setuju 9 orang $(26,47 \%)$, dan tidak setuju 5 orang $(14,71 \%)$.

Jawaban responden untuk pernyataan No. 8: Saya suka menyampaikan informasiinformasi penting kepada rekan kerja.Responden yang menjawab sangat setuju 5 orang $(14,71 \%)$, setuju 17 orang (50\%), kurang setuju 9 orang (26,47\%), dan tidak setuju 3 orang $(8,82 \%)$.

Jawaban responden untuk pernyataan No. 9: Rekan kerja selalu melibatkan saya dalam pembicaraan mereka.Responden yang menjawab sangat setuju 2 orang $(5,88 \%)$, setuju 20 orang $(58,82 \%)$, kurang setuju 7 orang $(20,59 \%)$, tidak setuju 4 orang $(11,76 \%)$, dan sangat tidak setuju 1 orang $(2,94 \%)$.

Jawaban responden untuk pernyataan No. 10: Saya mampu untuk mengerti apa yang sedang terjadi di lingkungan kerja. Responden yang menjawab sangat setuju 9 orang $(26,47 \%)$, setuju 14 orang $(41,18 \%)$, kurang setuju 6 orang $(17,65 \%)$, dan tidak setuju 5 orang $(14,71 \%)$.

\section{Variabel Efektivitas Kerja ( $\left.\mathbf{Y}_{1}\right)$}

Jawaban responden untuk pernyataan No. 1: Banyaknya volume pekerjaan yang saya terima sudah sesuai dengan kemampuan. Responden yang menjawab sangat setuju 3 orang $(8,82 \%)$, setuju 19 orang $(55,88 \%)$, kurang setuju 8 orang $(23,53 \%)$, dan tidak setuju 4 orang $(11,76 \%)$. 
Jawaban responden untuk pernyataan No. 2: Banyaknya volumen pekerjaansaya tidak menjadi hambatan dalam menyelesaiakan pekerjaan. Responden yang menjawab sangat setuju 5 orang $(14,71 \%)$, setuju 21 orang $(61,77 \%)$, kurang setuju 5 orang $(14,71 \%)$, dan tidak setuju 3 orang $(8,82 \%)$.

Jawaban responden untuk pernyataan No. 3: Saya mampu menyelesaikan pekerjaan lebih dari volume yang telah ditentukan. Responden yang menjawab sangat setuju 12 orang $(35,29 \%)$, setuju 15 orang $(44,12 \%)$, kurang setuju 6 orang $(17,65 \%)$, dan tidak setuju 1 orang $(2,94 \%)$.

Jawaban responden untuk pernyataan No. 4: Saya selalu teliti dalam melaksanakan pekerjaan yang diterima. Responden yang menjawab sangat setuju 6 orang $(17,65 \%)$, setuju 18 orang $(52,94 \%)$, kurang setuju 6 orang $(17,65 \%)$, dan tidak setuju 4 orang $(11,77 \%)$.

Jawaban responden untuk pernyataan No. 5: Hasil kerja saya selalu diterima oleh rekan kerja. Responden yang menjawab sangat setuju 5 orang $(14,71 \%)$, setuju 7 orang $(20,59 \%)$, kurang setuju 16 orang $(47,06 \%)$, dan tidak setuju 6 orang $(17,65 \%)$.

Jawaban responden untuk pernyataan No. 6: Waktu yang diberikan untuk pekerjaan kepada saya sudah sesuai dengan target perusahaan. Responden yang menjawab sangat setuju 5 orang $(14,71 \%)$, setuju 20 orang $(58,82 \%)$, kurang setuju 5 orang $(14,71 \%)$, dan tidak setuju 4 orang $(11,76 \%)$.

Jawaban responden untuk pernyataan No. 7: Ketepatan waktu saya merupakan faktor yang penting dalam menyelesaikan pekerjaan. Responden yang menjawab sangat setuju 3 orang $(8,82 \%)$, setuju 10 orang $(29,41 \%)$, kurang setuju 19 orang $(55,88 \%)$, dan tidak setuju 2 orang $(5,88 \%)$.

Jawaban responden untuk pernyataan No. 8: Saya selalu menyelesaikan pekerjaan dengan rapi. Responden yang menjawab sangat setuju 12 orang $(35,29 \%)$, setuju 19 orang $(55,88 \%)$, kurang setuju 1 orang $(2,94 \%)$, dan tidak setuju 2 orang $(5,88 \%)$.

Jawaban responden untuk pernyataan No. 9: Saya mampu menyelesaikan pekerjaan sebelum batas waktu yang ditetntukan. Responden yang menjawab sangat setuju 5 orang $(14,71 \%)$, setuju 4 orang $(11,76 \%)$, kurang setuju 10 orang $(29,41 \%)$, tidak setuju 14 orang $(41,18 \%)$, dan sangat tidak setuju 1 orang $(2,94 \%)$.

Jawaban responden untuk pernyataan No. 10: Jika pekerjaan tidak dapat dikerjakan sesuai waktu yang ditetapkan, saya memerlukan waktu tambahan.Responden yang menjawab sangat setuju 8 orang $(23,53 \%)$, setuju 6 orang $(17,65 \%)$, kurang setuju 10 orang $(29,41 \%)$, tidak setuju 8 orang $(23,5 \%)$, dan sangat tidak setuju 2 orang $(5,88 \%)$.

Dari hasil analisa penelitian yang dilakukan dengan bantuan software SPSS, diperoleh hasil bahwa variabel kecerdasan emosional berpengaruh positif dan signifikan terhadap efektivitas kerja karyawan di PT. Bank Aceh Syariah Cabang Meureudu. Hasil ini sejalan dengan hasil penelitian yang dilakukan oleh Nida Azzahra dan Riani Rachmawati di tahun 2013, yakni menunjukkan bahwa kecerdasan emosional berpengaruh positif terhadap efektifitas pemimpin, efektifitas tim, dan iklim pelayanan dengan dimediasi oleh kepemimpinan transformasional.

\section{KESIMPULAN}

Penelitian ini menyimpulkan bahwa pengaruh disiplin kerja, lingkungan kerja dan pemberian motivasi terhadap efektivitas kerja karyawan baik secara simultan maupun parsial 
sangat berpengaruh. Kecerdasan emosional organisasi secara simultan berpengaruh signifikan terhadap efektivitas kerja karyawan di PT. Bank Aceh Syariah Cabang Meureudu. Variabel kecerdasan emosional secara parsial berpengaruh signifikan terhadap efektivitas kerja karyawan di PT. Bank Aceh Syariah Cabang Meureudu.

\section{DAFTAR PUSTAKA}

Agustian, Ary Ginanjar. 2001. Rahasia Sukses Membangun Kecerdasan Emosi dan Spiritual, ESQ: Emotional Spiritual Quotient berdasarkan 6 Rukun Iman dan 5 Rukun Islam. Jakarta: Arga Wijaya Persada.

Cooper, R. Kand Sawaf, A. 1997. Executive EQ : Emotional Intelligence in Leadership and Organizations, New York, Berkeley Publishing Group.

Darwis, V. 2007. Budidaya, Analisis Usahatani, dan Kemitraan Stroberi Tabanan, Bali, Pusat Analisis Sosial Ekonomi dan Kebijakan Pertanian, Jakarta.

Goleman, Daniel. 1999. Working With Emotional Intelligence : Kecerdasan Emosi Untuk Mencapai Puncak Prestasi (penerjemah Alex Tri Kantjo Widodo). Jakarta: PT. Gramedia Pustaka Utama.

Handoko. 2001. Manajemen Personalia \& SDM, Yogyakarta, BPFE

Iman, E. 2004. Paradigma Baru Kecerdasan Emosional. Majalah Cakrawala TNI- AL. http:www. google.co.id. 